\title{
Operações e escavações em Franz Kafka e Primo Levi
}

\author{
Patricia Peterle ${ }^{1}$ \\ Departamento de Língua e Literatura Estrangeiras, Universidade Federal de Santa Catarina, \\ Florianópolis, SC, Brasil
}

\begin{abstract}
Resumo: Franz Kafka e Primo Levi são dois autores que marcam o século XX. Seus textos colocam o leitor diante daquele inacessível, indizível que escapa à linguagem. No primeiro há uma demanda por adentrar visceralmente nas aparências, ir além delas. No segundo, essa exigência se torna, a partir da experiência do Lager, em busca obsessiva por - mesmo na impossibilidade - tentar entender. Walter Benjamin, Primo Levi e Giorgio Agamben leitores de Kafka e Gilles Deleuze e Giorgio Agamben leitores de Levi.
\end{abstract}

Palavras-chave: Franz Kafka; Primo Levi; Walter Benjamin; Giorgio Agamben.

Title: Operations and excavations through Franz Kafka e Primo Levi

Abstract: Franz Kafka and Primo Levi are two authors that mark the 20th century. Their texts put the reader ahead of what is inaccessible, unspeakable, in others words ahead of those things that escapes from language. In the first there is a demand to go viscerally into appearances, to go beyond them. In the second, this demand becomes, from the experience of the Lager, in an obsessive search - even in the impossibility - to try to understand. Walter Benjamin, Primo Levi and Giorgio Agamben readers of Kafka and Gilles Deleuze and Giorgio Agamben readers of Levi.

Keywords: Franz Kafka; Primo Levi; Walter Benjamin; Giorgio Agamben.

Para Maria Aparecida Barbosa, pela admiração e pela amizade.

Algumas páginas ao longo do século XX expõem e tocam os limites entre literatura e pensamento. É, na verdade, o próprio vivido a expor o humano e o não-humano. Os estilhaços da história, entendida e lida aqui a contrapelo, falam e expõem as filigranas do humano. A produção artística resiste a percursos pré-estabelecidos ou obrigados e, exatamente por isso, exige um ritmo outro e próprio. Em seu Abecedário, Deleuze, ao tratar da palavra "resistência", chega a afirmar que as razões da arte e do pensamento fazem parte de certa "vergonha" de ser homem. Essa consideração e a intrínseca relação entre criação e resistência é trabalhada mais detidamente na conferência de 1987, dedicada, justamente, a essa relação.

\footnotetext{
${ }^{1}$ Mestrado e o Doutorado em Estudos Literários Neolatinos pela UFRJ. Pós-Doutorado em História pela UNESP e em Poesia Italiana pela Università degli Studi di Genova. Professora de Literatura Italiana do Departamento de Língua e Literatura Estrangeiras da Universidade Federal de Santa Catarina (UFSC). Pesquisadora do CNPq. Orcid: https://orcid.org/0000-0002-8990-3702

E-mail: patriciapeterle@gmail.com
} 
Para o filósofo, o escritor que melhor trabalhou com a complexidade dessa "vergonha" foi o italiano Primo Levi. A arte como o meio que libera a vida aprisionada pelo próprio homem é uma questão central para Deleuze: se o homem continuamente mata a vida, o artista a libera, a torna uma vida em potência. A existência de alguns personagens da narrativa, desde o início do século, já apontam para essa problemática que não deixa de ter ligações com o inexpressivo de Walter Benjamin, por agir, segundo Agamben "como uma instância crítica que freia o impulso cego e imediato da potência em direção ao ato e, dessa maneira, impede que ela se resolva e se esgote integralmente nele" (AGAMBEN, 2018, p. 67).

Franz Kafka na primeira metade do século XX e Primo Levi na segunda são dois escritores que trataram, cada um a seu modo e com suas obsessões, dessa vergonha acenada por Deleuze e, ao fazê-lo, expuseram às limitações da linguagem diante do inexpressível, do indizível. Não é um caso que a coleção da editora Einaudi, "Escritores traduzidos por escritores", é inaugurada justamente, com O processo, na tradução de Primo Levi. Uma outra tradução do romance kafkiano já havia sido realizada em 1973 por Giorgio Zampa. ${ }^{2}$ Se hoje podemos pensar em alguns pontos de contato entre as obras de Kafka e Levi, que trazem uma reflexão profunda sobre as relações, o próprio homem, os dispositivos que capturam a subjetividade e podem nos arrastar para um incessante processo de dessubjetivação, é interessante lembrar as declarações de Levi sobre o fato de Kafka não figurar entre seus escritores preferidos. A tradução do romance de Kafka não foi uma escolha pessoal de Primo Levi, foi sim uma decisão tomada em sede editorial, ou seja um convite que ele poderia ter recusado, mas acabou aceitando. Não se trata de desinteresse, Kafka talvez lhe esteja tão próximo, que essa proximidade exige, num movimento pela sobrevivência, certa distância de segurança.

É exatamente essa complexidade que pode ser percebida em relação ao Processo. Levi demonstra uma atitude que somente à primeira vista parece contraditória, mas que na verdade traz toda a problematização apontada por Deleuze ao tratar da "vergonha". Se de um lado, Levi se sente marcado pelo texto do romance a ponto de ter de se defender, dirá inclusive que se sente agredido, de outro, afirma ser um livro "belíssimo", que corta o corpo do leitor como uma lança, uma flecha, pelo fato de todos se sentirem processados. É essa ferida, que não fecha e cuja possível cicatriz é sempre uma marca, a grande questão. Dirá Levi na entrevista concedida a Federico De Melis, em 1983:

Kafka era judeu, eu sou judeu. O processo se abre com uma prisão não prevista e não justificada, minha carreira se abre com uma prisão não prevista e não justificada. Kafka é um autor que admiro, não o amo e o admiro, o temo como uma grande máquina de textos que despenca em cima

\footnotetext{
${ }^{2}$ Para as considerações de Primo Levi relativas à tradução, escolhas e diferenças, ver a entrevista concedida a Federico De Melis (LEVI, 2018, p. 363-364).
} 
de nós, como o profeta que nos dirá o dia da nossa morte. (LEVI, 2018, p. $363)^{3}$

Levi após ter experienciado o Lager talvez não tenha a necessidade de pensar o que está além das aparências e no subconsciente, como, faz segundo ele, Kafka, sua demanda é outra, é marcada por entender, por encontrar uma explicação, pela tentativa de desatar os nós - mesmo em sua impossibilidade. Todavia, essa demanda "outra", os aproxima. Pode-se dizer que Kafka pouco antes da Primeira Guerra teve a sensibilidade de intuir e perceber inúmeros indícios do que vinte anos mais tarde a Europa passaria. Três irmãs de Kafka mais novas (Elli, Valli e Ottla) morreram no campo de concentração, essa máquina corrupta e abjeta sobre a qual ele falou sem a conhecer. Uma intuição antecipadora, diz Primo Levi, ao notar que a violência é dada pela burocracia, esse poder que no século da barbárie cresce e se alastra tomando conta da vida; justamente por isso, tentar encontrar racionalidade e coerência significa desnaturalizar o livro que, de certa forma, já traz para o campo do literário o que Foucault mais de tarde chamará em suas análises de biopolítica. A cena final de 0 processo com a execução diante do céu azul parece ecoar mais de uma vez no primeiro romance de Levi, É isto um homem? (1947).

A linguagem é um elemento central nas escritas de Frank Kafka e Primo Levi, em suas operações materiais e imateriais, linguísticas e corpóreas. Aqui, ela é corpo que sente, que escapa e produz faíscas e falhas. A linguagem é operada de forma que suas funções comunicativas e informativas são desativadas, abrindo-as assim para um possível novo uso (AGAMBEN, 2018, p. 80). Os textos desses escritores jogam o fluxo do ser numa espécie de voragem ao concebê-lo, exatamente, como vórtice, na qual linguagem, contato, o outro e a relação, os dispositivos e contradispositivos são fundamentais.

O logos que caracteriza a metafísica ocidental e sua máquina é problematizado tanto por um quanto elo outro. ${ }^{4} \mathrm{E}$ aqui há um ponto central, quando a vida humana e a biológica passam a ser apresentadas unidas e confusas, por isso, seguindo Benjamin, é mais do que necessário pensar a catástrofe. Nessa linha, o livro publicado no final de 2018 pela Quodlibet, na Itália, que reúne os nove volumes publicados entre 1995 a 2005, dedicados à reflexão sobre - Homo Sacer, de Giorgio Agamben, é essencial para uma problematização mais contemporânea do estado de exceção, tratado por Carl Smith e Walter Benjamin, da economia, da guerra civil, dos dispositivos de inclusão-exclusão que têm dominado o panorama político internacional - e, às vezes, até parece que nos habituamos com esse

\footnotetext{
3 "Kafka era ebreo, io sono ebreo, II processo, si apre con un arresto non previsto e non giustificato, la mia carriera si apre con un arresto non previsto e non giustificato, Kafka è un autore che ammiro, non lo amo e lo ammiro, lo temo, come una grande macchina che ti viene addosso, come il profeta che ti dirà il giorno della tua morte" (LEVI, 2018, p. 363).

${ }^{4}$ Massimo Cacciari em relação ao Castelo de Kafka chegar a falar que a paralisia fruto do comando é a perfeita execução: o comando que paralisa. Continuando nos passos do filósofo, a impossibilidade da ordem é seu próprio sentido, mas o reconhecimento de sua insensatez não é a solução, pois é algo da esfera do inadmissível para o logos (CACCIARI, 2002).
} 
horror. E, sobretudo, um repensar a própria linguagem, que é o mais antigo dos dispositivos. Em qualquer uma dessas esferas, seja qual for o poder soberano, há um paradoxo instaurado que é discutido desde o primeiro capítulo de Homo sacer:

Não é a exceção que se subtrai à regra, mas a regra que, suspendendo-se, dá lugar à exceção e somente deste modo se constitui como regra, mantendose em relação com aquela. O particular "vigor" da lei consiste nessa capacidade de manter-se em relação com uma exterioridade. Chamemos relação de exceção a esta forma estrema da relação que inclui alguma coisa unicamente através de sua exclusão. (AGAMBEN, 2002, p.26)

A nua vida, ou seja, o grau zero da vida, conceito essencial da pesquisa realizada pelo filósofo italiano - que se apresenta na atualidade como uma exigência - é tomado emprestado das leituras de Benjamin, e não pode ser pensado sem esse paradoxo da inclusão-exclusão. De um lado a vida biológica a "zoé" e do outro sua politização, a boa vida, "bios". É a separação entre elas que produz a vida do homo sacer. A vida, com seu caráter sacer, se torna o centro da política, tanto em relação aos campos de concentração, quanto aos refugiados da nossa atualidade. Joseph K., diante da porta em O processo, é o personagem escolhido para se pensar a coincidência entre corpo, existência e processo: a lei, aliás, a pura forma de lei, coincide com a vida, ou seja, o momento em que ela, não prescrevendo nada e expondo-se, se reafirma com mais força e intensidade. Benjamin leitor de Kafka, e Agamben leitor de Benjamin e Kafka: "E é exatamente uma vida deste gênero, em que a lei é tão mais disseminada enquanto carente de qualquer conteúdo e na qual uma pancada distraidamente dada em uma porta desencadeia processos incontroláveis, aquela que Kafka descreve" (AGAMBEN, 2002, p.60).

Se Kafka foi um autor lido e relido por Benjamin, e seus rastros perpassam também por vários escritos de Agamben, sendo ele talvez um dos escritores mais citados, Levi não o acompanha tão de perto, mas é fundamental para a reflexão sobre a arte e a política. Auschwitz. o arquivo e o testemunho, originalmente $\mathrm{O}$ que resta de Auschwitz, é, contudo, o livro que parte dos questionamentos colocados por Levi. Agamben recupera a figura do mulçumano, the dedica uma atenta análise para pensar inclusive nossa atualidade. Paralelamente, retoma uma leitura do próprio Levi acerca dos poemas de Paul Celan, em que o escritor italiano trata da obscuridade do poeta (AGAMBEN, 2002, p.187-194). Para Levi, a obscuridade muitas vezes apontada não é de desprezo em relação ao leitor, na verdade tal operação, na língua alemã, é comparada a um último e desarticulado balbuciar, a algo que deveria ser dito mas não o foi, há um rumor de fundo que aponta para o indizível. A linguagem escura e incompleta de Celan pode ser, assim, pensado ao lado daquele que está no ponto de morte e encontra-se sozinho. Em suas diferentes temporalidades, e contemporâneos ao próprio tempo, Kafka e Levi em seus textos - que veremos detalhadamente mais adiante trazem como matéria prima para seu laboratório uma relação direta com a história e seus estilhaços - lida por eles benjaminianamente a contrapelo -, com a exposição do não- 
humano, com a engrenagem maquínica das normas, incluindo aqui a própria linguagem. São operações literárias que suspendem o próprio dispositivo da narração mais tradicional, abrindo uma escavação na própria narrativa, que como disse Levi em relação a Kafka, causam perturbações e inquietações.

\section{Operações e escavações: Franz Kafka e Primo Levi}

O processo de Kafka, escrito entre 1914-15 e publicado póstumo, é um texto desafiador e inquietante. Joseph K. é feito prisioneiro por dois policiais, devido à abertura de um processo. $O$ "processo" que gera e engendra toda a narrativa, presente em sua ausência, talvez seja o grande protagonista do romance, uma vez que toda a vida de Joeph K., a partir de um determinado momento, passa a ser regida por essa ação da qual não se tem notícias mais claras ou mais concretas. Todo o aparato processual, aos poucos, vai engolindo o personagem, que de seguro de seus atos (inclusive de sua própria inocência) passa, com o tempo, a ser consumido por toda a engrenagem, visível e não, que começa a funcionar ao seu redor: o fantasmático maquinário das leis. No conversa com o padre, no capítulo "Na Catedral", quando da discussão sobre a parábola do camponês diante da porta, cujo porteiro afirma não ser o momento de entrar, há um fragmento que parece ser chave para se pensar esse e outros textos do autor: "A ideia exacta de qualquer assunto e a não compreensão do mesmo assunto não se excluem" (KAFKA, s/d, p.225). Quando se está diante da Lei, se está diante de dispositivos que a representam, a expressam e a comunicam. E é nesse sentido que Kafka expõe a complexidade do sujeito, trazendo-a para o centro de sua atenção e de seus questionamentos, num gesto que lança também luz para a problematização da linguagem. Uma linguagem que fala, paralisa, silencia e, ao mesmo tempo, é compreendida e não compreendida; seus limites são colocados à prova na medida em que o literário, numa complementariedade, se volta para fora e para dentro e "tem como conteúdo senão dizer sua própria forma" (FOUCAULT, 2007, p. 416). A literatura, então, configura-se como um espaço de limiar, resistência-criação. Se por um lado Kafka mostra o poder da língua, sua ordem normativa, seu poder penetrante, por outro, ilumina sua corrosão, seus silêncios. A relação estabelecida desde o início entre a esfera da linguagem e a do direito - analisada por Agamben minuciosamente em sua arqueologia-filológica - já havia sido ressaltada por Walter Benjamin: "O que é a corrupção no mundo do direito, a angústia é no mundo do pensamento. Ela perturba o pensamento, mas constitui o único elemento de esperança que ele contém" (BENJAMIN, 1994, p. 157) E ainda continua Benjamin, "Kafka é sempre assim; ele priva os gestos humanos dos seus esteios tradicionais e os transforma em temas de reflexões intermináveis" (BENJAMIN, 1994, p. 147). Nessa linha, a linguagem pode ser vista como um dos "esteios" principais, uma vez que Joseph K., obviamente, não a perde, ela está ali, mas é como se estivesse sido suspensa - emudecida - e, por isso mesmo, ele vai se paralisando e vai se transformando numa figura espectral. A linguagem dentre os dispositivos de controle e de dessubjetivação talvez seja um dos mais antigos "em que há milhares e milhares de anos um 
primata - provavelmente sem se dar conta das consequências que se seguiriam - teve a inconsciência de se deixar capturar" (AGAMBEN, 2009, p. 41). A pergunta-título do ensaio de Judith Butler "Can One Lead a Good Life in a Bad Life?" (2012), outra leitora da obra de Benjamin, vai no centro da questão, pois obriga ao embate com a pergunta: como vivo essa vida que é a minha? Há uma diferença grande em conduzir a vida e ser guiado por algo. A vulnerabilidade é um dos aspectos centrais tratados por Butler, que afirma que os corpos são vulneráveis diante de outros corpos e das instituições, ela pode ser explorada e manipulada o corpo que é com certeza humano, em algumas situações é tratado como animal humano.

Tais problemáticas aparecem num outro texto de Kafka de poucos anos depois, A colônia penal de 1919. As relações entre vida-morte-linguagem-poder são novamente atravessadas e operadas a partir de todo um sistema que, nesse caso em particular, gira ao redor de uma concreta máquina - também da linguagem - construída por um antigo general da Colônia. Uma ilha na qual é construída todo um sistema de punição, como já indica o adjetivo "penal". Ordem, obediência, disciplina são mais do que sentimentos temidos e partilhados por todos dentro da rígida hierarquia. A trama tem como mote a "indisciplina" de um soldado diante de seu superior, e é por isso condenado. Na verdade, o soldado que havia cochilado em serviço, se assusta com a chegada e repreensão de seu superior, reagindo instintivamente. A insubordinação se dá num momento em que o soldado não está totalmente consciente, pois sua ação foi uma reação ao grito que o acordou. A denúncia de insubordinação é feita e o soldado condenado. Não se tem praticamente nenhuma informação referente à denúncia, porém, em compensação, se tem uma descrição minuciosa da máquina de tortura, construída pelo antigo comandante, e de seu funcionamento. Nas condenações da Colônia há todo um procedimento ritual de exposição e espoliação, que se de um lado consagra a desmesura do poder, do outro, conserva, pela morte e na morte, a memória viva do antigo comandante. Toda a descrição do funcionamento da "geringonça" da morte tem como mote a chegada de um explorador que desequilibra ainda mais as linhas de força do poder constituído. ${ }^{5} \mathrm{O}$ momento da condenação do soldado é, com todo seu cerimonial, usado pelo responsável pela máquina como tentativa de convencer o explorador da grande invenção que ela é e representa. A fala do oficial é precisa, descreve peça por peça, o soldado condenado, por sua vez, acompanha atento os movimentos, os gestos, todo o preâmbulo de sua morte anunciada pela condenação (sem julgamento); contudo, pouco consegue acompanhar, pois o oficial e o explorador se comunicam numa língua que ele não entende. Há aqui uma situação paradoxal, aquela ocasião só pode existir por causa da condenação, mas o condenado principal interessado, que faz com que a própria trama exista, participa não-participando de todo esse preâmbulo ritualístico da explicação por não compartilhar a língua, ou seja, é excluído sem o sê-lo.

\footnotetext{
${ }^{5} \mathrm{Na}$ verdade, é preciso dizer que o novo comandante da Colônia, personagem que só é nomeado, praticamente não aparece na narrativa - justamente por isso -, não concordava muito com o regime de punição da máquina, orgulho de seu antecessor.
} 
Como aponta Agamben, "De facto, as explicações não são mais do que um momento na tradição do inexplicável: o momento que toma conta dele, deixando-o inexplicado" (1999, p.136). Todos sabemos que condenação é a inscrição da sentença na pele com agulhas, ou seja, é quando morto ou quase que o condenado sente na pela a sentença, sem ainda talvez sabê-la. Ao término de toda sua explanação o oficial espera receber o consenso e a concordância do explorador. Mas, ao verificar que isso não acontece, insiste em continuar demonstrando sua convicção, contudo, agora, retira o condenado que já estava com pernas e mãos atados e muda a sentença para "Sê justo", colocando-se e se posicionando no centro das operações, no lugar do condenado. Um dado que chama a atenção é como ele conhecia, manuseava e dominava toda a máquina. O que ele queria provar com isso? Seu absoluto controle? Seu caráter destemido diante da própria morte? De todo modo, a engrenagem começa a funcionar fazendo emitindo alguns ruídos estranhos: "Aquilo que não podia ser explicado está perfeitamente contido naquilo que não explica mais nada" (AGAMBEN, 1999, p.136). A máquina não grava mais as letras da sentença "Sê justo", no corpo ali presente, agora, parece funcionar de forma diferente daquela da explicação dada momentos antes. De fato, a máquina parece seguir ao comando "Sê justo", desativando seu normal funcionamento e entrando em colapso. Ela, portanto, obedece sim a sentença, mas, para isso, ela mesma precisa ser destruída - ou se autodestruir.

A linguagem, nesses dois textos de Kafka, está entre as problemáticas centrais, é sua filigrana. É de dentro de suas "entranhas" que Joseph K., aos poucos, emudece e é também por meio dela que o soldado condenado assiste toda a explicação de sua suposta morte sem partilhar a língua, numa singular relação de inclusão-exclusão. "A linguagem comunica a essência linguística das coisas. Mas a manifestação mais clara dessa essência é a própria linguagem" (BENJAMIN, 2011, p.53). Nesse sentido, a máquina de tortura poderia ser lida como uma complexa alegoria da linguagem, que julga e pune. Por isso, o "comando" para sua destruição é, justamente, "Sê justo", isto é sua própria impotência, da qual ela não pode fugir. Dirá Benveniste que uma língua sem expressão da pessoa é praticamente inconcebível, que a linguagem é a possibilidade de subjetividade, que ela enfim oferece formas "vazias" (1976, p. 284-292). As cesuras abertas expõem o sentido da linguagem, sua intrínseca aporia: um "funcionamento" lógico e suas fraturas, uma vez que o "poeta é aquele que fala sem entendimento" (BLANCHOT, 2011, p.47).

Esse falar sem entendimento é levado a uma máxima potência com a experiência traumática e limite da Segunda Guerra, o desarticulado balbuciar do qual fala Levi em relação a Celan. Em seu Feuilletz d'Hypnos (1946) René Char, por meio de aforismas - forma mais do que significativa nesse momento - fala da experiência na Resistência francesa, vivida como o capitão Alexandre, o nome de batalha de oficial no exército clandestino de liberação. Na nota que antecede o livro, o poeta afirma que essa escrita deu-se na tensão, na cólera, no medo, na emulação, no desgosto, na dissimulação, na ilusão do futuro, na amizade e no amor (aforismos 19, 39, 59, 62, 83). 
Char compartilha de uma experiência que é também questionada que por outros artistas e escritores. A experiência da guerra exige uma outra forma de escrita que não pode continuar sendo a mesma. Questão que remete à famosa sentença de Adorno ao dizer que não seria possível escrever poemas depois de Auschwitz, posição que depois será revista ao dizer que "a dor perene tem tanto direito à expressão como o torturado ao grito: por isso pode ter sido errado afirmar que não se pode escrever mais nenhum poema após Auschwitz" (1975, pp. 362-363). A dialética entre o desejo pelo conhecimento e o que ele gera está colocada no aforismo 39 de Char, o fato de se conhecer pressupõe por si só uma tomada de posição, mesmo que silenciosa. É também nesse viés, mas num outro momento histórico - o do boom econômico e suas consequências -, do predomínio da técnica, para retomar o que foi colocado por Benjamin, e não só, que Italo Calvino encerra As cidades invisíveis, com a última fala de Marco Polo:

O inferno dos vivos não é algo que será; se existe, é aquele que já está aqui, o inferno no qual vivemos todos os dias, que formamos estando juntos. Existem duas maneiras de não sofrer. A primeira é fácil para a maioria das pessoas: aceitar o inferno e tornar-se parte deste até o ponto de se deixar de percebê-lo. A segunda é arriscada e exige atenção e aprendizagem contínuas: tentar saber reconhecer que e o que, no meio do ínfero, não é inferno, e preservá-lo, e abrir espaço. (1990, p. 150)

Tensão que retorna no aforismo 59 de Char. A tarefa que fica para quem participou dessa experiência devastadora é, justamente, como lidar com essa herança avassaladora que não possui um testamento. Eis, então, a questão paradoxal trazida por Primo Levi, para a qual Agamben chama atenção em $O$ que Resta de Auschwitz?: o vivenciar algo da esfera do indizível, aquele vivido não se traduz em palavras, mas mesmo assim, é preciso tentar dizê-lo, lembrá-lo para não esquecer, há uma questão ético-política. São as imagens dos "mulçumanos", os submersos, a força do campo, os não-homens, que povoam a memória de Levi, como ele diz no capítulo que Ihes dedica:

Eles povoam minha memória com sua presença sem rosto, e seu pudesse concentrar numa imagem todo o mal do nosso tempo, escolheria essa imagem que me é familiar: um homem macilento, cabisbaixo, de ombros curvados, em cujo rosto, em cujo olhar, não se possa ler o menor pensamento. (1988, p. 91)

Há um processo de emudecimento (não muito distante do de Joseph K.), recolhimento dentro de si - perda inclusive desse si - que se dá dentro de toda a aparelhagem e organização, dentro do sistema de dispositivos instaurado campo. Outra imagem, agora num outro registro, pois É isto um homem?, é uma mistura de registros, de línguas que apontam 
justamente para a dificuldade de tratar dessa experiência do não-dito, é a descrição do "mulçumano" não mais de forma objetiva como se viu na citação anterior.

Quando fala, quando olha, dá a impressão de estar interiormente oco, nada mais do que um invólucro, como certos despojos de insetos que encontramos na beira dos pântanos, ligados por um fio às pedras e balançados pelo vento. $(1988$, p.41)

Um fragmento do romance de tom mais poético, mesmo na sua dureza, em que o "muçulmano" não é comparável nem a um inseto, mesmo que talvez ainda tenha um faro instintivo, ele é oco, vazio, nem morto e nem vivo, daí o termo "despojos", resíduo de um corpo, que está à mercê do vento e, provavelmente, de outras condições externas, enfim vulnerável para retomar o termo de Butler. A eles, diz-se num outro fragmento, nem adianta dirigir a palavra. São esses homens não-homens a força do campo, sua energia vital, sua segurança de sobrevivência, à medida em que eles vão se consumindo e apagando, o campo se mantém vivo, e eles cada vez mais extremados, exaustos, esgotados não tem mais como sofrer. Talvez tenham até perdido, no silêncio, "na opaca solidão íntima" (1988, p. 90), a palavra e com ela seus significados. E justamente nessa ranhura, nesse vazio do invólucro em que algo é rompido, que pode ser pensado o gesto de escavação de Primo Levi, que ao olhar e falar da própria experiência trata de uma página fundamental da nossa história mais recente. Nesse sentido, pensar a ideia, ou melhor o gesto de escavar se torna fundamental na leitura desses textos.

A língua tem indicado inequivocamente que a memória não é um instrumento para a exploração do passado; é, antes, o meio. É o meio onde se deu a vivência, assim como o solo é o meio no qual as antigas cidades estão soterradas. Quem pretende se aproximar do próprio passado soterrado deve agir como um homem que escava. Antes de tudo, não deve temer voltar sempre ao mesmo fato, espalhá-lo como se espalha a terra, revolvê-lo como se revolve o solo. Pois "fatos" nada são além de camadas que apenas à exploração mais cuidadosa entregam aquilo que recompensa a escavação. (BENJAMIM, 1987, p. 239)

Língua e memória dois aspectos necessários e que são traços constituintes do humano, se encontram entrelaçados neste outro texto de Benjamin. Se recuperarmos a última parte dessa citação, é colocado que não se deve "temer" voltar sempre ao mesmo fato, que este deve ser explorado como um arqueólogo explora seu território de investigação, não poderíamos aqui pensar na escrita de Primo Levi? Autor de vários romances, contos, poemas. Engenheiro químico que se faz escritor, por uma necessidade existencial de explorar essas camadas, de compartilhá-las, de estabelecer relações possíveis contra o esquecimento da desumanização do homem pelo próprio homem durante a Segunda Guerra, que com outras roupagens ainda assola nosso viver. Não interessa a Primo Levi fazer um inventário do 
passado, como aponta Hanna Arendt é o futuro que impele esse retorno (2002, p. 37), ou se quisermos retomar "Escavando e recordando":

E se ilude, privando-se do melhor, quem só faz o inventário dos achados e não sabe assinalar no terreno de hoje o lugar no qual é conservado o velho. Assim, verdadeiras lembranças devem proceder informativamente muito menos do que indicar o lugar exato onde o investigador se apoderou delas. A rigor, épica e rapsodicamente, uma verdadeira lembrança deve, portanto, ao mesmo tempo, fornecer uma imagem daquele que se lembra, assim como um bom relatório arqueológico deve não apenas indicar as camadas das quais se originam seus achados, mas também, antes de tudo, aquelas outras que foram atravessadas anteriormente. (BENJAMIN, 1987, p. 239-240).

A questão é também o fato de não se estar preparados para pensar diante dessa lacuna entre passado e futuro (ARENDT, 2002, p. 37). É, exatamente, nessa lacuna-abismo que para Levi se dá a aproximação com a escrita, justamente, por meio experiência lacerante como prisioneiro no campo de concentração de Monowitz, entre dezembro de 1943 e outubro de 1945, que fazia parte do complexo de Auschwitz-Birkenau. Há uma vontade de exteriorizar, uma vontade de narrar para não esquecer, uma exigência ética e também política. A postura do cientista de raízes iluministas, a confiança no trabalho (trabalho também de escrita), a relação com a memória cujas marcas estão no corpo, o desejo de estabelecer relações com as coisas são todos elementos partícipes de sua escrita, que talvez tenha em toda a sua diversidade um único tema.

É isto um homem é publicado num momento em que havia uma exigência da e na cultura italiana de olhar para si, para a realidade, para esquemas "populares" que haviam sido banidos, disfarçados, e até proibidos pelo fascismo. Nesse contexto, o parecer da Einaudi, em 1946, para a publicação do livro é negativa, as feridas contidas nessas páginas ainda estavam abertas. ${ }^{6}$ O romance sai por uma pequena editora Silva (de Franco Antonicelli), em 1947 e só dez anos depois será publicado pela Einaudi.

\footnotetext{
${ }^{6}$ Em entrevista a Ferdinando Camon, Conversazione con Primo Levi (1987), Levi afirma o fato de ter ficado surpreso por ter sido uma pessoa da literatura italiana e judia, quem deu o parecer negativo. Anos mais tarde, a identidade do parecerista é confirmada pelo editor Giulio Einaudi, numa entrevista, em que afirma que foi Natalia Ginzburg. Talvez a lembrança daquela violência humana, as perseguições a shoah tenham significado um reviver todas aquelas sensações para alguém que também havia perdido o marido, Leone Ginzburg (colaborador da editora), em janeiro de 1944, na prisão depois de ser torturado. A recusa da publicação aponta para o fato de como o assunto, ou melhor, a relação com a questão, ainda tão recente, era complexa. Além disso, a escrita de Levi desviava dos caminhos neorrealistas, trata-se de pensamentos íntimos, sobretudo, reflexões sobre um acontecido que ele decide partilhar. Uma intimidade que se abre, como de certa forma também acontece com Natalia Ginzburg, em 1963, quando da publicação de Léxico familiar, que não deixa de tocar na perseguição sofrida por sua família sob o regime de Mussolini. Ela, como Levi, traz para o centro da narrativa a palavra falada (a oralidade) a comunidade nela sobrevivente e presente e os contatos que ela também é capaz de gerar; ambos estão à escuta dos ecos, os rastros de ecos dos
} 
$E$ isto um homem? se distancia das perspectivas neorrealistas que predominavam nesse momento do imediato pós-guerra. A lembrança e o relato da vivência no campo de concentração se desdobra entre narrativa e diário - interessante recuperar as últimas páginas do livro a esse respeito - em que se alternam e se sobrepõem temporalidades diferentes: presente, o momento em que escreve, passado, o tempo da história vivida. O fio condutor do livro é o período no lager, mas cada capítulo pode ser pensado de forma independente, como se fossem flashes daquela experiência que retornam contra o esquecimento, acontecimentos isolados alinhavados pelos fios de um dos "estilhaços" (interessante usar esse termo, pois o caco de estilhaço como o caco desta memória fere); ou ainda uma espécie de via crucis. Diz Levi no prefácio "O livro foi escrito para satisfazer essa necessidade em primeiro lugar, portanto, com a finalidade de liberação interior. Daí, seu caráter fragmentário: seus capítulos foram escritos não em sucessão lógica, mas por ordem de urgência." (LEVI, 1988, p. 8). É diante dessa necessidade, a de comunicabilidade, a do outro, que são tecidos os 18 capítulos.

Muitos, pessoas ou povos, podem chegar a pensar, conscientemente ou não, que "cada estrangeiro é um inimigo". Em geral, essa convicção jaz no fundo das almas como uma infecção latente; manifesta-se apenas em ações esporádicas e não coordenadas; não fica na origem de um sistema de pensamento. Quando isso acontece, porém, quando o dogma não enunciado se torna premissa maior de um silogismo, então, como último elo da corrente, está o Campo de Extermínio. Este é o produto de uma concepção do mundo levada às suas últimas consequências com uma lógica rigorosa. Enquanto a concepção subsistir, suas consequências nos ameaçam. A história dos campos de extermínio deveria ser compreendida por todos como sinistro sinal perigo. (LEVI, 1988, p.8)

Um recordar que é uma reflexão, ao mesmo tempo sobre si, sobre as relações construídas, sobre aquilo que o fez sobreviver a todos os dispositivos de desumanização instaurados e acionados diariamente por todos que partilhavam o espaço delimitado pelo arame farpado. Reflexão cujos alicerces estão no dia a dia da vida do campo, o barro, a luz intensa, a escuridão, os cheiros, as diferentes línguas, a fome. Um estado de exceção que, com o tempo, com o habituar-se da vida cotidiana ali, parece ser e se apresenta como algo da normalidade. A resistência de Levi de não se adaptar totalmente, de se recusar (aprendendo também com outros prisioneiros) a viver naquela condição como ordinária, vem do fato de ele não ter se fechado, de ter buscado sempre uma relação, o outro, como aparece nos inúmeros nomes evocados. Talvez, tenha sido essa exterioridade, necessária à sobrevivência, que tenha alimentado o que é possível manter de vida num espaço marcado pela não-vida.

A sensação de estar fora do mundo, descrita em "No Fundo", é corroborada por todos os indícios de "desconforto", de um lugar inóspito e, ao mesmo tempo, hospedeiro: das

discursos que se desviam em cheiros, sensações, cores. Todos fragmentos de um tempo ido, que pertence ao sujeito, mas só é presente por meio de "estilhaços" de memória. 
diferentes línguas, aos diferentes silêncios, à sensação continua de sede e de fome (fome não só física), ao sapato com sola de madeira que provoca feridas sempre ardentes, à crueldade e fadiga do trabalho que paradoxalmente significa a possibilidade de vida. Inclusive a mesma matéria prima que serve para delimitar o campo, o arame, é a usada para amarrar os sapatos, costurar os botões do uniforme, assim como a cerca elétrica é adaptada para fazer suspensórios. Todo um sistema de inibição e que dificulta as relações consigo mesmo e com o outro. O próprio corpo passa a ser um espaço de exposição de ausências e, sobretudo, de "chagas" físicas que talvez pudessem aniquilar dores não físicas. O várias menções, por exemplo, à mistura entre barro, sangue, sapatos e pé é o início do contato físico com esse terreno. Todo esse processo de dessubjetivação, a nua vida, é anunciado no momento em que os prisioneiros são despojados de todos os pertences pessoais, tendo ainda os cabelos raspados: "não há espelhos, mas a nossa imagem está aí na nossa frente, refletida em cem rostos pálidos, em cem bonecos sórdidos e miseráveis. Estamos transformados em fantasmas como os que vimos ontem à noite" (LEVI, 1988, p.24). O que resta de mais íntimo e pessoal é a lembrança, que o sistema do campo vai também minando com o tempo.

Ao fazer uma resenha para o segundo livro de Levi, A Trégua, o poeta Vittorio Sereni diz tratar-se de um "mundo informe, atemporal, sub-humano: uma espécie de hipótese atroz de uma 'nova' forma de vida sem indivíduos, quase uma antecipada - por sua vez atroz paródia de uma sociedade sem classes" (SERENI, 2013, p. 876). ${ }^{7}$ Como narrar toda essa experiência do humano não-humano, do caráter oco? Diante da força que emudece, há a necessidade íntima de falar, mas talvez, e é isso que nos coloca Levi, seja preciso reaprender a falar depois de ter vivido "a confusão das línguas [...] um elemento constante da nossa maneira de viver; a gente fica no meio de uma perpétua babel, na qual todos berram ordens e ameaças em línguas nunca antes ouvidas (Brot, Broit, chleb, pain, lechem, kenyér)"(LEVI, 1988, p.36). "Em um dia bom", a torre da fábrica muito alta é comparada à Torre de Babel: "fomos nós que a construímos. Seus tijolos foram chamados Ziegel, briques, tegula, cegli, kamenny, bricks, téglak" e foram acimentados com ódio e discórdia, como a Torre de Babel, por isso assim a chamam "Balbetrum": "e odiamos nela o sonho demente de grandeza dos nossos patrões, seu desprezo de Deus e dos homens, de nós homens" (LEVI, 1988, p. 73).

Noi non possiamo non com-parire. Soltanto, al limite, la massa fascista tende ad annientare la comunità nel delirio di una comunione incarnata. E analogamente il campo di concentramento - e di sterminio, il campo di concentramento dello sterminio - è, nella sua essenza, volontà di distruggere la comunità. Ma mai, nemmeno nel campo di concentramento, la comunità cessa completamente di resistere a questa volontà. Essa è in un certo senso la resistenza stessa, la resistenza all'immanenza. La comunità, quindi, è la trascendenza; ma la 'trascendenza' che cessa di avere un significato 'sacro' non significa appunto nient'altro che la resistenza all'immanenza (alla

\footnotetext{
${ }^{7}$ Interessante lembrar que essa resenha sai um ano antes da publicação de Gli strumenti umani (1965), que contém o texto dedicado a Anne Frank, e de Pietà ingiusta e Opzione.
} 
comunione di tutti o alla passione esclusiva di uno o di qualcuno: a tutte le forme e a tutte le violenze della soggettività) (NANCY, 1992, 78-79).

É, portanto, nessa tensão-resistencial que Primo Levi escreve, como ele mesmo, de algum modo, testemunha numa das digressões colocadas nessas páginas:

Aqui está minha irmã, e algum amigo (qual?), e muitas outras pessoas. Todos me escutam, enquanto conto do apito em três notas, da cama dura, do vizinho que gostaria de empurrar para o lado, mas tenho medo de acordá-lo porque é mais forte que eu. Conto também a história da nossa fome, e do controle de piolhos, e do kapo que me deu um soco no nariz e logo mandou que me lavasse porque sangrava. É uma felicidade interna, física, inefável, estar em minha casa, entre pessoas amigas, e ter tanta coisa para contar, mas bem me apercebo de que eles não me escutam. Parecem indiferentes; falam entre si de outras coisas, como se eu não estivesse. Minha irmã olha para mim, levanta, vai embora em silêncio. (LEVI, 1988, p. 60)

Nesse sentido, o personagem Lourenço parecer ser central, pois é a ele que leve atribui sua sobrevivência. Mais uma vez, é ressaltado o valor da relação ("com esse seu jeito tão simples e fácil de ser bom"), de fato, foi Lourenço que fez com que se mantivesse a esperança de um mundo fora dali, "uma possibilidade remota de bem pela qual valia a pena conservarse", mesmo numa condição em que a "humanidade ficou sufocada, ou eles [os priosineiros] mesmos a sufocaram, sob a ofensa padecida ou infligida a outros" (LEVI, 1988, p. 124). Como aponta Franco Fortini, num texto publicado por ocasião da morte de Primo Levi, em sua escrita há um constante desejo de entender, uma exigência e demanda de busca. Herdeiro do racionalismo laico, de tradição gobettiana, o que conta para Levi são as relações entre os homens, a indecifrabilidade de seus (FORTINI, 2003, pp. 1681-1683). Levi em sua escrita não polariza humano e não-humano, ele mostra exatamente a tensão existente, sua escrita tem, na verdade, um forte sentido da vida e da necessidade de defendê-la a todo momento, pois como lemos em vários episódios de É isto um homem?, tudo ali existia para aniquilá-la. A última frase do romance retorna para a questão apontada aqui, a necessidade da relação, do contato, do outro - movimentos em que a linguagem é central. De fato, antes da indicação da data, Levi se recorda de um companheiro de nome Charles, com quem compartilhou, os dias em que o campo estava morto, momento no qual tiveram a ocasião de recuperar uma humanidade esquecida. Ambos fora do campo, retomaram suas vidas, se comunicam por meio de cartas, Charles voltou a ensinar e Levi expressa o desejo: "Espero pode revê-lo algum dia." (LEVI, 1988, p. 175).

Parece que hoje escavar a história, tarefa incansável empreendida por Walter Benjamim em seus escritos, e perceber os dispositivos que a todo momento nos capturam é uma urgência também presente em nossa contemporaneidade. 


\section{Referências}

ADORNO, Dialéctica negativa. Trad. José María Ripalda. Madrid: Taurus 1975.

AGAMBEN, Giorgio. "O que é um dispositivo?". In: AGAMBEN, Giorgio. O que é o contemporâneo e outros ensaios. Trad. Vinicius Nicastro Honesko. Chapeco: Argos, 2009.

AGAMBEN, Giorgio. Homo Sacer: o poder soberano e a vida nua I. Trad. Henrique Burigo. Belo Horizonte: Editora UFMG, 2002.

AGAMBEN, Giorgio. Ideia de Prosa. Trad. João Barrento. Lisboa: Cotovia, 1999.

AGAMBEN, Giorgio. O fogo e o relato. Trad. Patricia Peterle e Andrea Santurbano. São Paulo: Boitempo, 2018.

ARENDT, Hanna. Entre o passado e o futuro. São Paulo: Perspectiva, 2002.

BENJAMIN, Walter. Escritos sobre o mito e linguagem. Trad. Susana Kapf Lages, org. Jeanne Marie Gagnebin. São Paulo: Duas Cidades, Editora 34, 2011.

BENJAMIN, Walter. Obras Escolhidas I - Magia e técnica, arte e politica. Trad. Sérgio Paulo Rouanet. São Paulo: Editora Brasiliense, 1994.

BENVENISTE, Emile. Da subjetividade na linguagem. In: BENVENISTE, Emile. Problemas de linguística geral. Trad. Maria da Glória Novak, Luiza Neri. São Paulo: Editora USP, 1976, pp. 284-292.

BLANCHOT, Maurice. O espaço literário. Trad. Álvaro Cabral. Rio de Janeiro: Rocco, 2011.

BUTLER, Judith. Can One Lead a Good life in a Bad Life? In: BUTLER, Judith. Radical Philosophy. Adorno Prize Lecture, September 11, 2012. Published Nov/Dec 2012.

CACCIARI, Massimo. Icone della legge. Milano: Adelphi, 2002.

CALVINO, Italo. As cidades invisiveis. Trad. Diogo Mainardi. São Paulo: Companhia das Letras 1990.

FORTINI, Franco. Saggi e epigrammi. Org. Luca Lenzini. Milano: Mondadori, 2003, p. 16811683.

FOUCAULT, Michel. As palavras e as coisas. Trad. S. Tannus Michail. São Paulo: Martins Fontes, 2007.

KAFKA, Franz. O processo. Trad. Maria José Fabião. Lisboa: Europa-América, s/d.

LEVI, Primo. É isto um homem? Tradução de Luigi del Re. Rio de Janeiro: Editora Rocco, 1988, p. 8.

LEVI, Primo. Opere complete III. Org. Marco Belpoliti, Turim: Einaudi, 2018.

NANCY, Jean-Luc. La comunità inoperosa. Traduzione di Antonella Moscati. Napoli: Cronopio, 1992.

SERENI, Vittorio. Poesie e prose. Org. Giulia Raboni. Milano: Mondadori, 2013.

Recebido em: 16/04/2019

Aceito em: 23/08/2019 